\title{
Individual Techniques of Professional Development: A Critical Review of Literature
}

\author{
Matseliso L Mokhele \\ University of Fort Hare \\ E-mail:mmokhele@ufh.ac.za
}

\section{Doi:10.5901/mjss.2014.v5n20p2934}

\begin{abstract}
The need for high quality professional development is a central component in nearly every modern proposal for improving the quality of education in South Africa and abroad. Indeed, if all students are to succeed, they must have teachers who know how to teach every student to a high standard. Unfortunately, many teachers, especially in developing countries, do not have the necessary skills to do this nor are they equipped to confront the challenges and adverse conditions they face in trying to improve the quality of education in the schools. It is therefore necessary to find appropriate professional development approaches to ensure that all the teachers, even the most experienced ones, are equipped with the necessary knowledge and skills for improving learner performance. Teachers also need to broaden their knowledge and improve their skills over the course of their careers. It is no surprise that funders, educators and researchers all suggest professional development for improving the quality of education in schools. This paper therefore explores the techniques of professional development specifically on the individual techniques.
\end{abstract}

Keywords: Professional development, continuing professional development, techniques of professional development

\section{Introduction}

In education, continuing professional development (CPD) is increasingly becoming a priority in most countries throughout the world. It is widely viewed as the most effective approach to prepare teachers adequately, and improve their instructional and intervention practices, for when they enter the workforce (Fraser et al 2007). In other words, the CPD of teachers is one of the key factors in ensuring that education reforms, at any level, are effective. International evidence seems to suggest that the progress of educational reforms depends on the individual and collective capacity of teachers and its link with the school-wide promotion of the education of pupils (Stoll et al 2006). Building the capacity to do so is thus critical, and that is what CPD aims to achieve. There has recently been a significant increase in the level of interest and support that teachers throughout the world are receiving in their professional development. Evidence of this, as cited by Villegas-Reimers (2003), is listed below:

$>$ Extensive literature regarding professional development is available. This includes documents, essays and research reports on models and practices of professional development.

$>$ International and national donor agencies have commissioned studies so that they can learn how to support such development more effectively.

$>$ Many national and international organisations have supported the implementation of initiatives which aim to improve the professional skills and knowledge of teachers.

> Most educational reforms currently being designed and/or implemented include a component of teacher professional development as one of the key elements in the process of change.

There is a general agreement that learning to teach is a lifelong process. This notion of professional learning for teachers as continuous has been emphasised by several researchers such as Zeichner and Noffke (2001). Providing meaningful professional development for in-service teachers is seen as central to this goal. The meaning of in-service education is changing and it varies from country to country depending on the level of preparation teachers receive prior to entering the profession (Villegas-Reimers, 2003). Bolam (1982:3) notes that, for most, if not all developed countries, inservice education and training includes:

those education and training activities engaged in by primary and secondary-school teachers and principals, following their initial professional certification, and intended mainly or exclusively to improve their professional knowledge, skills and attitudes in order that they can educate children more effectively

Studies on the effects of collaborative action research have found that experienced (in-service) teachers become more reflective, critical, and analytical about their teaching behaviours in the classroom when they engage in 
collaborative research (Rainey, 2000; Smith, 2005; McDonough, 2006). However, in most parts of the world the majority of in-service programmes are too short, too unrelated to the needs of teachers, and too ineffective at teaching knowledge (Villegas-Reimers, 2003). In addition, Atay (2007) argues that current In-Service Education and Training programmes (INSET) are often unsatisfactory because they do not allow teachers to be actively involved in their development or reflect on their teaching experiences.

Emanating from the different perspectives and philosophies on CPD, a number of types and models of teacher professional development have been developed and implemented in different countries. The goal has been to promote and support the professional development of teachers from the beginning of their careers until they retire. In the sections that follow, I examine some of the most prominent types of CPD in recent literature. These models include: professional development schools, distance education, teacher networks or school networks, workshops, seminars, courses, university-school partnerships, observations of excellent practice, and the "training of trainers" models. This raises an important question for those creating professional development programmes: which one of these models is most likely to lead to the desired goals? It is important to point out at this stage that the models are described separately here for clarity and distinction, but that most professional-development initiatives use a combination of models simultaneously, and that these combinations vary from setting to setting.

\section{Literature review}

In the following section, I present the individual model or techniques of professional development. These are those models that can be implemented on a smaller scale (a school or classroom). Many of these have been identified as techniques of professional development rather than models.

\subsection{Teacher workshops}

One of the most common forms of professional development is the typical in-service staff training which uses workshops, seminars and courses. In South Africa, state-initiated transformation requirements, together with the enormous amount of under-qualified teachers trained during the apartheid era, have resulted in an increase of in-service teacher training courses offered by university education departments. The provincial education departments, such as the Gauteng Department of Education (GDE), have taken on the responsibility of presenting continuous professional development (CPD) workshops to assist teachers in the General Education Band (GEB) to improve their skills. However, the changes have been so widespread that it has been impossible to train all teachers adequately with the regular support services of the Education Department. Consequently, the Department of Education decided to contract teacher training institutions to assist with the process of CPD (Lessing and De Witt, 2007). These institutions are similar to the former Pretoria Teacher's Training College (now University of Pretoria) which was contracted to improve the subject knowledge and skills of Gauteng teachers in outcomes-based education. The training was presented as a workshop over six Saturdays, and covered mathematics, language development, reading and spelling, and learner assessment.

In their research, Cutler and Ruopp (1999) also describe a workshop-style initiative in which the staff at the Education Development Centre in the USA designed and implemented a programme of professional development entitled the 'Middle School Mathematics Project'. Cutler and Ruopp note that as part of the project, middle school mathematics teachers from the Boston area of the USA met twice a month for two years to attend half-day workshops that addressed issues related to teaching mathematics; some of these workshops were content-based, while others focused on pedagogical knowledge and practice. The teachers involved consider the workshops to have been very valuable as their practices in the classroom improved. In an effort to understand the teachers' opinions on the value of the workshops (particularly with regard to CPD, personal development and improving their teaching approach), Cutler and Ruopp learned that teachers found the CPD workshops important with regard to: personal and skills development, support, providing new information, confidence, and changing teaching habits. Almost $90 \%$ of the teachers viewed the provision of knowledge as one of the positive aspects of the CPD workshops. However, many researchers are critical of the workshops and believe most of them to be single experiences which are fragmented, incoherent, decontextualised and isolated from the real classroom environment (Collinson and Ono, 2001; Villegas-Reimers, 2003; OECD, 2005 ) .

Fullan (1991:315) argues that:

Nothing has promised so much and has been so frustratingly wasteful as the thousands of workshops and conferences that led to no significant change in practice when the teachers returned to their classroom.

The same dissatisfaction is observed in the research on professional development of teachers in developing countries (Villegas-Reimers, 2003; Leu, 2004; MacNeil, 2004). One of the findings of the review committee on the 
implementation of Curriculum 2005 was that "there is virtually no ongoing support and development when teachers are back on site after receiving orientation and training at workshops (Review Committee on Curriculum 2005, 2000:61). Research has also shown that very few teachers actually participate in high-quality professional development because the predominant mode of professional development for the majority of teachers is still "one-shot" workshops which are often not focused on subject matter (Garet et al 2001).

Lessing and Witt (2007) also contend that the teachers who attended OBE workshops in South Africa had a negative attitude towards most of these presentations because they did not supply enough applicable knowledge and skills for use in their classrooms, or for addressing the problems they experience in their work environment. Because these workshops were presented on weekends, some teachers felt that they had to sacrifice too much time and that it was too much effort in comparison to what they had gained. The expectation that they would have an understanding of outcomes-based education and be able support learners with learning difficulties in an inclusive classroom had not been met. Similar results were obtained in a study by Swart, Engelbrecht, Eloff and Pettipher (2002:183) in which teachers had a negative attitude towards in-service training (a form of CPD) as they felt that they had not acquired the knowledge or skills which would allow them to appropriately address the diversity in their classrooms. However, given the new understanding of professional development as an ongoing process of growth and learning, there are cases that show that workshops, seminars and courses, when accompanied by other types of professional development, can be successful.

\subsection{Observation of excellent pracrice}

A number of professional development programmes offer teachers the opportunity to observe colleagues who have been recognised for their expertise and excellence in teaching. Teachers therefore have the opportunity to learn from the knowledge, skills and attitudes that excellent teachers implement in the classroom (Villegas-Reimers, 2003). In his example of this model, Villegas-Reimers (2003) refers to the Teachers International Professional Development Programme, implemented by the British council, which sponsors British teachers to visit schools in a variety of countries. This is done in order for British teachers to observe, first-hand, new aspects of teaching, so that they can share their experiences with other teachers in their schools and communities.

A similar programme also referred to by Villegas-Reimers (2003) is the United Kingdom/Australia fellowship scheme for teachers of Science. This programme, funded by the governments of both the UK and Australia, provides funding for a handful of teachers from one of these countries to travel to the other country and observe practice, participate in research projects, attend workshops and enter discussions with other teachers (Robottom and Walker, 1995). This programme has been very successful in promoting teachers' professional development. In the South Africa the MSSI project in Mpumalanga, as cited by Ono and Ferreira (2010), sought to improve the quality of mathematics and science education by enhancing the teaching skills of in-service teachers. More specifically, although this was not stated in the project document, it aimed to institutionalise 'lesson study', a form of school-based continuing professional development wherein a teacher conducts a study lesson, which is observed by other teachers. The observers listen attentively to all contributions made by the learners and document any important remarks and behaviours of the teacher and learners that are related to achieving the lesson outcomes. On a more informal level, there are a number of programmes - including both pre-service and in-service - that offer opportunity-es for less experienced teachers to shadow and observe master teachers doing their job.

\subsection{Portfolios}

In the past few years, portfolios have gained increasing support in education from students, teachers, and school administrators for a variety of reasons. Portfolios were initially introduced to address a variety of student assessment concerns regarding the authenticity of tasks, learning over time, and the application of knowledge. In addition, portfolios reflected and integrated many current theoretical perspectives on teaching and learning such as constructivism, scaffolding, and peer coaching (McLaughlin and Vogt, 1998).

A portfolio, as defined by Riggs and Sandlin, (2000) is a collection of items gathered over a certain period of time to illustrate different aspect of a person's work, professional growth and abilities. However, in teaching, a portfolio is usually a tool used to engage teachers and students in discussions about topics related to teaching and learning (Villegas-Reimers, 2003). A teaching portfolio is a purposeful collection of evidence assembled by a teacher consisting of descriptions, documents, examples of good teaching, and moreover, a teacher's thoughts on their educational practice (including illustrations of its complexity) The use of portfolios in the teaching profession began during the late 1980s in the work of the Teacher Assessment Project at Stanford (Wolf, 1991). According to Wolf (1991, p.130), as an alternative form 
to assessment, portfolios represented a way to define, display, and store "evidence of a teacher's knowledge and skills that is based on multiple sources of evidence collected over time in authentic settings" (in Delandshere and Arens, 2003). There are three forms of portfolios that are normally used by educators: (1) An employment portfolio; (2) an assessment portfolio (as a way of assessing their competence and outcomes); and (3) a learning portfolio (a collection of items that help teachers to think about, and describe learning outcomes (Diets, 1999).

These three forms of portfolio, according to Frederic, McMahon and Shaw (2000) and Lally (2000) are referred to as evaluation, assessment and employment portfolios; teachers use both their evaluation and employment portfolios mainly to discuss their best work. They are advised to do this so that their educational skills can be demonstrated. A development portfolio, which is also referred to as a learning portfolio, focuses on a teacher's process of reflection when they compile a teaching portfolio. Teachers should try to improve their teaching practice with the aid of a development portfolio (Lally, 2000). Portfolios seem to be a preferred method of assessment for making decisions about teaching. Many teacher education programmes require prospective teachers to develop portfolios to prepare them for licensing or relicensing. In parallel with teachers' use of portfolios, many schools have begun using them as part of their pre-service programmes with teachers in order to facilitate self-reflection, document growth on performance-based tasks, and promote a sense of professional efficacy (Tucker et al 2003).

One of the strengths of a portfolio identified by educationists is that it allows individual learners to express themselves. Through a portfolio, they argue, candidates have an opportunity to be the focal point, work at their own pace, and cover content of their choice. In this way the learner is in control and feels more valued (Brown and Knight, 1999). In their research, De Rijdt et al (2006) found that due to the use of portfolios, the respondents were compelled to reflect on their own teaching, to actualise the learning content, to improve their course materials and to search for alternative educational methods, etcetera. In a qualitative case study of two elementary schools in Fresno, California, that implemented teacher portfolio evaluation, Stone and Mata (1996) interviewed and surveyed participants about their perceptions of portfolio-based teacher evaluation. The coding categories that emerged from their thematic analysis noted numerous potential benefits which included the following:

$>$ "More authentic, personal, and realistic". Both teachers and administrators found the process more of a reflection of the practices in the classroom.

> "Captures the whole picture". Teachers see this as a better way to look at a teacher's programme in its entirety.

$>$ "Felt good about it." Teachers felt reinforced and supported by the process.

$>$ "Constructive criticism was part of the conversation".

$>$.Administrators encouraged analysis, reflection, and self-evaluation.

> "Made me look at what I'm doing more critically"; "Portfolio conference promoted professional development" (Stone and Mata, 1996:8-9)

In perhaps the most comprehensive study to date on portfolios, Bond, Smith, Baker, and Hattie (2000) examined the validity of the National Board for Professional Teaching Standards' (NBPTS) portfolio based teacher assessment process. The NBPTS has established standards for the advanced certification of teachers in 20 different fields and has certified more than 10,000 teachers (Harman, 2001). In its certification process, the NBPTS has relied heavily on a portfolio evaluation system since its inception in 1987 (NBPTS, 1991). In their study, Bond et al (2000) investigated whether "National Board Certified teachers and their non-certified counterparts can be distinguished on the basis of the quality of work produced by their students" (p.viii).

The researchers reviewed instructional lesson plans, made observational visits to the classrooms, and analysed samples of the work of 65 teachers' students. Their findings indicated that the National Board Certified teachers in this sample obtained higher mean scores on 13 "attributes of expert teaching that have emerged from the ever-expanding body of research on teaching and learning" (Bond et al 2000:ix) than the noncertified teachers; the study also found statistically significant differences between 11 of the 13 attributes. The students of National Board Certified teachers also exhibited differences in comparison to those of the noncertified teachers. In their submitted work, the students demonstrated "an understanding of the concept targeted in the instruction that [was] more integrated, more coherent, and [had] a higher level of instruction than understanding achieved by other students" (Bond et al 2000).

This comprehensive construct validation study supported the premise that the portfolio-based assessment system could distinguish between experienced and inexperienced teachers and thus address one accountability purpose for teacher evaluation (Tucker et al 2003). Although there is encouraging news regarding the application of portfolios for the accountability and professional growth of teacher evaluation, research regarding the effectiveness of portfolios as a measure of teacher quality is limited, particularly regarding issues such as utility, validity, and reliability (ibid). Borko et al (1997) made a case for the use of teacher portfolios more than a decade ago. Tucker et al (2003:255) also cautioned that 
it remains to be seen whether, in any conditions, the school teacher's portfolio can be useful either for schoolteachers or for their administrators.

In agreement with this Tisani (2006) adds that there are also some contradictions in some of the claims that are made about portfolio assessment, such as discrepancies between the theoretical claims and practice. For example, claims of greater learner control in the assessment process are compromised by the fact that the whole process is still summative and the assessor still passes final judgment. The unpredictability of portfolio assessment can lead to puzzling complexities or unexpected surprises for both the assessor and assessed (Biggs, 2003). In South Africa, Tisani (2008) cites an example of the professional development of academic staff at a South African university. The account deals with an initiative to develop academics into assessors and accredit them as such after they have completed a relevant module and have met its requirements. The module was to be assessed through a portfolio. In her conclusion, Tisani (2008) argues that many of the respondents did not produce a portfolio; they attributed their unfamiliarity with the use of portfolios as the main reason for doing so and most probably found it 'an alien form of discourse'. Some of the respondents even questioned the appropriateness and efficacy of portfolio assessment and highlighted the logistical issues as barriers to their learning.

\subsection{The training of trainer's model or the cascade model}

In this model, a first generation of teachers is trained or educated on a particular topic, aspect of teaching or subject matter, and once proficient, become the educators of the second generation (Griffin, 1999). Ono and Ferreira (2010) argue that the cascade or multiplier approach is often used to transmit the knowledge or information from the upper to the lower groups of teachers. This entails training the trainer to ensure that knowledge is transferred from experts and specialists to the teachers. In many developing countries the cascade approach is popular for reaching many participants in a short period of time (Leu, 2004). The advantages of this training model are that it allows training to take place in stages so that progress can be monitored and, as more teachers receive training, information can be disseminated quickly and to an even larger number of teachers. In theory, cascade training is cost-effective as those who have been trained can then train others, thus minimising expenses (Ono and Ferreira, 2010).

In his example, Prescott (2000) describes the School-Attuned Project, in which a small number of teachers were taught, through case studies, how to identify and diagnose eight areas of brain functioning. In his conclusion, Prescott contends that these teachers, in turn, taught their colleagues to complete the same assessment. This project had very positive effects on the teachers, the learners and learners' families. In South Africa, this model was initially used as an advocacy strategy by the Department of Education to provide CPTD to teachers to enable them to implement the new national curriculum (Engelbrecht et al 2007). The other example cited by Jita et al (2008) is the MSSI project where one of the approaches to training and development was to have university experts first train the curriculum implementers who then presented it, in turn, to the cluster leaders. The cluster leaders then trained the teachers at school level. The knowledge can be seen to have cascaded from a few experts on an upper level, all the way down to a large community of school teachers.

The cascade model has however, been widely criticised as an inadequate model for delivering effective training (Khulisa, 1999; HSRC, 2000). When the intended message is transmitted to the next level, the chances of crucial information being misinterpreted are high (Fiske and Ladd, 2004). The approach failed to prepare either officials or school-based teachers for the complexity of the implementation of the new national curriculum. Ono and Ferreira (2010) documented how teachers frequently complained that even the district trainers themselves did not always understand the curriculum. The result was the "watering down and/or misinterpretation of crucial information" (Fiske and Ladd, 2004:162). Robinson (2002) and Graven (2002) also discuss the dissatisfaction with the cascade model that introduced teachers to the new curriculum in South Africa. Robinson (2002) argues that this model offers training, but with little or no follow-up support structures for teachers who have to deal with the long-term implementation of the new reforms. This concern coincides with the apprehension that a serious challenge facing South African education in general is the lack of any successful translation of new curriculum reforms into classroom practice. This is despite the wide use of professional development to help teachers understand the new reforms (Rogan and Grayson 2003).

\subsection{Coaching/mentoring}

A review of research on teacher coaching suggests that when teachers are provided with the opportunity to meet with peer coaches or expert coaches to discuss implementation, they are more likely to implement strategies and to adopt strategies that are relevant to their needs (Joyce and Showers, 2002). Mentoring has become one of the most common 
methods to help new teachers and research shows that as a model, it is popular with both mentors and beginner teachers (Ballantyne and Hansford, 1995). Mentoring/coaching is defined by Harwell-Kee (1999) as a process by which a colleague, who is a critical listener/observer, asks questions, makes observations and offers suggestions that help a teacher to develop, reflect upon, and execute different skills.

This process provides opportunities and structure for teachers' professional development. Mentoring is a form of coaching that tends to be short-term (for beginner teachers or teachers new to a school or education system) but which can also be ongoing and long-term (Holloway, 2001). Coaching is a learned skill and therefore coaches and mentors also need to be trained. A mentor provides a newcomer with support, direction, feedback, problem solving guidance, and a network of colleagues who share resources, insights, practices and materials (Robbins, 1999). Mentoring is one form of professional development that affects both new teachers who are being mentored, and experienced teachers who serve as mentors. According to Ballantyne and Hansford (1995), mentors have many tasks to execute: sharing information, providing access to resources, being a role model, counselling, coaching, encouraging reflection, providing career advice and supporting new teachers. In their research carried out in Australia, Ballantyne and Hansford (1995) report that the effects of 'buddy mentoring' (having a companion teacher) are very positive, but not sufficient. New teachers need access to other mentoring resources, such as specialists, consultant teachers, faculty from teacher-preparation institutions, and other resources. One of the examples from South Africa that is discussed by Wilmot (2004) is the situation in which a university tutor identifies and approaches experienced teachers to act as tutors. Generally, teachers recognise the pedagogical benefits of mentoring Postgraduate Certificate in Education (PGCE) students who have fresh, innovative ideas and a thorough knowledge of curriculum changes. In other examples of mentoring as a form of professional development, Hawkey (1998) examined how two different mentoring styles (one that focuses on providing multiple opportunities for the student teachers to learn and one that focuses on particular teaching experiences of student teacher) affected the learning process of their students. Both were found to be effective, and when the style matched that of the student teacher, the experience was positive. In addition, Holloway (2001) reports on some studies that show that mentors who have received some form of mentor training are often more effective in their roles.

\section{Conclusion}

To make informed policy and programme decisions regarding teacher professional development, district and school leaders need to know whether professional development programmes are currently reaching the teachers who need them most. And most specifically they would need to know and identify the techniques of professional development.

\section{References}

Atay, D. 2007. Teachers professional development: partnership in research. Teaching English as a second or foreign language 10 (2): 115

Ballantyne, R. and Hansford B. 1995. "Mentoring beginning teachers: a qualitative analysis of process and outcomes". Educational Review 47(3):297-308.

Biggs, J. 2003. Teaching for quality learning at University: what the student does. Second edition. Buckingham, UK: SRHE \& Open University Press.

Bolam, R. 1982. In- service education and training of teachers: a condition of educational change. Final report of CERI project on INSET. Paris: OECD.

Bond, L., Smith, T., Baker, W.K., and Hattie, J.A. 2000. The certification system of the national board for professional teaching standards: a construct and consequential validity study. Greensboro: centre for educational research and evaluation, the University of North Carolina at Greensboro.

Borko, H., Michael, P., Timmons, M. and Siddle, J. 1997. Student teaching portfolios: a tool for promoting reflective practice. Journal of Teacher Education 48 (5): 345-356.

Brown, S. and Knight, P. 1999. Assessing matters in higher education: choosing and using diverse approaches. Buckingham, UK: SRHE \& Open University press.

Collinson, V. and Ono, Y. 2001. The Professional Development of Teachers in the United States and Japan. European Journal of Teacher Education 24(2): 223-248.

Cutler, A.B. and Ruopp ,F.N. 1999. "From expert to novice: the transformation from teacher to learner". In: Solomon, M.Z. (Ed), and the diagnostic teacher: constructing new approaches to professional development. New York: teachers college press.

Delandshere, G. and Arens, S.A. 2003. Examining the quality of the evidence in pre-service teacher portfolios. Journal of Teacher Education 54 (1): 57-73.

De Rijdt, C., Tiquet, E., Dochy, F. and Devolder, M. 2006. Teaching portfolios in higher education and their effects: an explorative study. Teaching and Teacher Education 22 (8):1084-1093. 
Dietz, M.E. 1999. "Portfolios". Journal of Staff Development 20(3):45-46.

Engelbrecht, W., Ankiewicz, P. and Swardt E. 2007. An industry- sponsored, school-focused model for continuing professional development of technology teachers. South African Journal of Education 27:579-595.

Fiske, E.B. and Ladd H.F. 2004. Elusive equity: education reform in post-apartheid South Africa. Washington: DC: Brookings institute.

Fraser, C., Kennedy, A., Reid, L. and Mckinney, S. 2007. Teachers continuing professional development: contested concepts, understanding and models. Professional Development in Education 33 (2): 153-169.

Frederic, L., McMahon, R. and Shaw, E.L. 2000. Pre-service teacher portfolios as autobiographies. Education 120 (4):634-638.

Fullan, M. 1991. The new educational change. London: Cassell.

Garet, M.S., Porter, A.C., Desimone, L.M., Birman, B., and Yoon, K.S. 2001. What makes professional development effective? Results of a national sample of teachers. American Educational Research Journal 38(3):915-945.

Graven, M. 2002. Coping with new mathematics teacher roles in a contradictory context of curriculum change. The Mathematics Educator 12 (2):21-27.

Griffin, M. 1999. "Training of trainers". Journal of staff development 20(3):52-53.

Harman, A.E. 2001. National board for professional teaching standards' national teacher certification (report no: EDO-sp-2001-6). Washington, D.C: ERIC clearinghouse on teaching and teacher education, American Association of colleges for teacher education.

Harwell-kee, K. 1999. Coaching. Journal of Staff Development 20 (3):28-29.

Hawkey, K .1998. "Mentor pedagogy and student-teacher professional development: a study of two is mentoring relationship". Teaching and Teacher Education 14(6): 657-670.

Holloway, J.H. 2001. "The benefits of mentoring". Educational Leadership 58(8): 85-86.

Human Science Research Council. 2000. Formative evaluation and monitoring of curriculum 2005 implementation in Gauteng: preliminary report submitted to Gauteng institute for curriculum development. Pretoria: Human Science Research Council.

Jita, L.C.,Ndlalane, T.C. and Maree, J.G. 2008. How much Science do South African teachers know? In B Wallance (ed). Proceedings of the 17 th Biennial Conference: World council for Gifted and talented children. Warwick, UK.

Joyce, B. and Shower, B. 2002. Student achievement: through staff development (Third edition). Alexandria: Association for supervision and curriculum development.

Khulisa Management Services. 1999. Evaluation of OBE/C2005 In Gauteng Province: presentation of final results. (Unpublished report). Johannesburg: Gauteng Department of Education/ Gauteng institute of curriculum development. Johannesburg: Global print.

Lally, A .2000.Teaching portfolios and the continuous improvement of teaching. Art Documentation 19(1):48-49.

Lessing, A. and De Witt, M .2007. The value of continuous professional development: teachers' perceptions. South African Journal of Education 27(1): 53-67.

Leu, E. 2004. The patterns and purposes of school-based and cluster teacher professional development programs (EQUIP1 Working Paper No.2). Washington, D.C.: U.S. Agency for international development.

MacNeil, D.J. 2004. School and cluster based teacher professional development: bringing teacher learning to the school. Working Paper 1 under EQUIP 1's study of school based teacher in-service programs and clustering of schools.

McDonough, K. 2006. Action research and the professional development of graduate teaching assistant. Modern Language Journal 90 (1): $33-47$.

McLaughlin, M.W. and Vogt, M.E 1998. Portfolio assessment for in-service teachers: a collaborative model. In professional portfolio models: applications in education (pp.1-76). Norwood, MA: Christopher- Gordon publishers.

NBPTS. 1991. Towards high and rigorous standards for the teaching profession (Third edition): national board for professional teaching standard, Washington, D.C.

OECD (Organization for Economic Co-operation and Development). 2005. Teachers matter: attracting, developing and retaining effective teachers. Education and training policy division, directorate for education. Paris.

Ono,Y. and Ferreira, J. 2010. A case study of continuing teacher professional development through lesson study in South Africa. South African journal of Education 30: 59-74.

Prescott, J.O. 2000. "All kinds of minds". Instructor 109 (7):17-20.

Rainey, O. 2000. Action research and the English as a foreign language practitioner: time to take stock. Educational Action Research 8: 65-91.

Review Committee on Curriculum 2005. 2000. South African curriculum for the twenty first century. Report of the Review committee on curriculum 2005. Pretoria. (Unpublished report).

Riggs, I.M. and Sandlin, R.A. 2000. "Teaching portfolios for support of teachers"professional growth". NASSP Bulletin 84 (618): $22-27$.

Robbins, P. 1999. "Mentoring". Journal of Staff Development 20 (3):40-42

Robinson, M. 2002. Teacher Reforms in South Africa: Challenges, strategies and debates. Prospects 11(3): 289-99

Robottom, I. and Walker, R.1995. "The UK/Australia Science teacher fellowship program: a journey in professional development". School Science Review 77(278):21-29.

Rogan, J.M. and Grayson, D.F. 2003. Towards a theory of curriculum implementation with particular reference to Science education in developing countries. International Journal of Science Education 25 (10):171-204.

Smith, P.S. 2005. The impact of action research on teacher collaboration and professional growth. In D.Tedick (ED), second language teacher education: international perspectives (pp.199-213). Mahwah, NJ:Erlbaum.

Stoll, L., Bolam, R., McMahon, A., Wallace, M. and Thomas, S. 2006. Professional Learning communities: A review of the literature. 
Journal of Educational Change 7: 221-258.

Stone, B. and Mata, S.1996. Capturing the whole picture: portfolios and professional conversation in teacher evaluation. Paper presented at the annual meeting of the American Educational Research Association, New York.

Swart, E., Engelbrecht, E., Eloff, I, and Pettipher, R. 2002. Implementing inclusive education in South Africa: teacher's attitude and experiences. Acta Academica, 34: 175-189.

Tisani, N. 2006. Assessment by portfolio: an encounter with contradictory discourses. South African Journal of Higher Education 20(3):546-57.

Tisani, N. 2008. Challenges in producing a portfolio for assessment: in search of underpinning educational theories. Teaching in Higher Education 13(5):549-557.

Tucker,P.M., Stronge, J.H., Gareis, C.R. and Beers, C.S. 2003. The efficacy of portfolios for teacher evaluation and professional development: do they make a difference? Educational Administration Quarterly 39 (5): 572-602.

Villegas-Reimers, E.2003. Teacher professional development; an international review of the literature. Paris: UNESCO, International institute for educational planning.

Wolf, K. 1991. The school teacher's portfolio: issues in design, implementation, and evaluation. Phi Delta Kappan. 129-136.

Wilmot, D. (2004). Emerging models of teacher training: The case of South Africa. International Research in Geographical and Environmental Education, 13(2), 153-158.

Wise, A. 2000. "Creating a high quality teaching force". Educational Leadership 58(4):18-21

Zeichner, K. and Noffke, S. 2001. Practitioner research in V.Richardson. handbook of Research on teaching.pp298-332. Washington, DC-4th edition, American Educational Research Association. 